Research.

\title{
Analysis on joint operation non administrative accounting models of property development firms and the impact on taxation
}

\author{
Indar Khaerunnisa ${ }^{1^{*}}$, Amrullah ${ }^{2}$ \\ $1^{*}$ Department of Accounting, Universitas Binaniaga Indonesia, Bogor, Indonesia \\ ${ }^{2}$ Institut Bisnis dan Informatika Kesatuan, Bogor, Indonesia \\ ${ }^{1 *}$ bundaabdadabsyar@gmail.com, ${ }^{2}$ ulloh@ibik.ac.id \\ ${ }^{*}$ Corresponding author
}

Received: March 22, 2020; Accepted: May 17, 2020; Published: June 30, 2020.

To cite this article: Khaerunnisa, Indar, and Amrullah. (2020). Analysis on joint operation non administrative accounting models of property development firms and the impact on taxation. The Accounting Journal of BINANIAGA. 5 (1): 45-60. doi: 10.33062/ajb.v5i01.367

Abstract. This study aims to determine the accounting model in conducting joint operations (JO) by implementing non-administrative which consists of fix profit and percentage. Each fixed profit has three methods consisting of full revenue, profit sharing and PMK 261. The research used a descriptive qualitative method, with a case study approach. The study used primary data obtained from direct interviews with directly related parties conducting joint operations (JO or KSO). Meanwhile, the secondary data were obtained from the mutual agreement document and the financial report of the party conducting the joint operation (KSO). From the research results, it is obvious that the most recommended form of accounting is all forms according to PMK 261, both the fixed profit and percentage models.

Keywords: Administrative Joint Operation, Non Administrative, Fixed Profit.

\section{INTRODUCTION}

In property business, ranging from development of housing, apartments, office buildings and other property products, land surveys, land purchases, request building rights certificates on behalf of the developer, plan-making and preparation of all permits are carried out prior to development. However, recently, these activities have been abandoned because purchasing new land are costing and too risky. Instead, the properties developers prefer to use the latest trends, i.e. cooperation with landowners to jointly conduct business in property development. The form of joint operation (KSO) between developers and landowners includes land payments and profit sharing. In this business scheme, land payments can be made within the term of time or at the end of the joint operation when the unit is sold out. Meanwhile, profit sharing is in accordance with the percentage of profit and with fixed profit, which has been decided according to the agreement.

In the joint operation (KSO) scheme, there are two methods of accounting models, i.e. administrative and non-administrative method. In conducting joint operation (KSO), many developers tend to conduct non-administrative operations which in its implementation of joint operation (KSO), companies often encounter with taxation problems where there are tax burdens which have not been calculated before. It occurs because there are inconsistent tax treatments in the joint operations (KSO) between one and the other, causing uncertainty for taxpayers. At the end of the cooperation, there is the potential for a reduction in corporate profits due to unpredictable expenses. 


\section{LITERATURE REVIEW}

In this study, literature review is applied to use agency theory in which, it is assumed that principals and agents are economic actors who think rationally and act solely for personal gain, but they find difficulty in distinguishing differences in reference, trust and information. In this research, the principal is meant by the government/state that has the right to collect taxes on citizens, in the interest of national development. The agent referred to in this study is the developer who conducts self-assessment.

\section{RESEARCH METHOD}

The study used descriptive qualitative research with a case study approach. Case studies are included in the descriptive analysis research, i.e. research carried out focused on a particular case to be observed and analyzed thoroughly until it is complete so that an accurate conclusion will eventually be obtained. Primary data were obtained from interview results with the parties involved in joint operations (KSO), such as developers, while the secondary data were obtained from the cooperation agreement (PKS) document and the financial report of the developer conducting the joint operation (KSO) with the landowner.

\section{RESULTS AND DISCUSSIONS}

Joint operation (KSO) of property development business can be performed by implementing non-administrative joint operations (KSO). In this method, accounting is generally divided into two forms, namely fixed profit and percentage. In each accounting model, i.e. fixed profit and percentage, there are 3 forms of accounting on sale namely full revenue, share revenue and based on PMK261. Out of the operational cooperation accounting models, the following basic comparisons can be described:

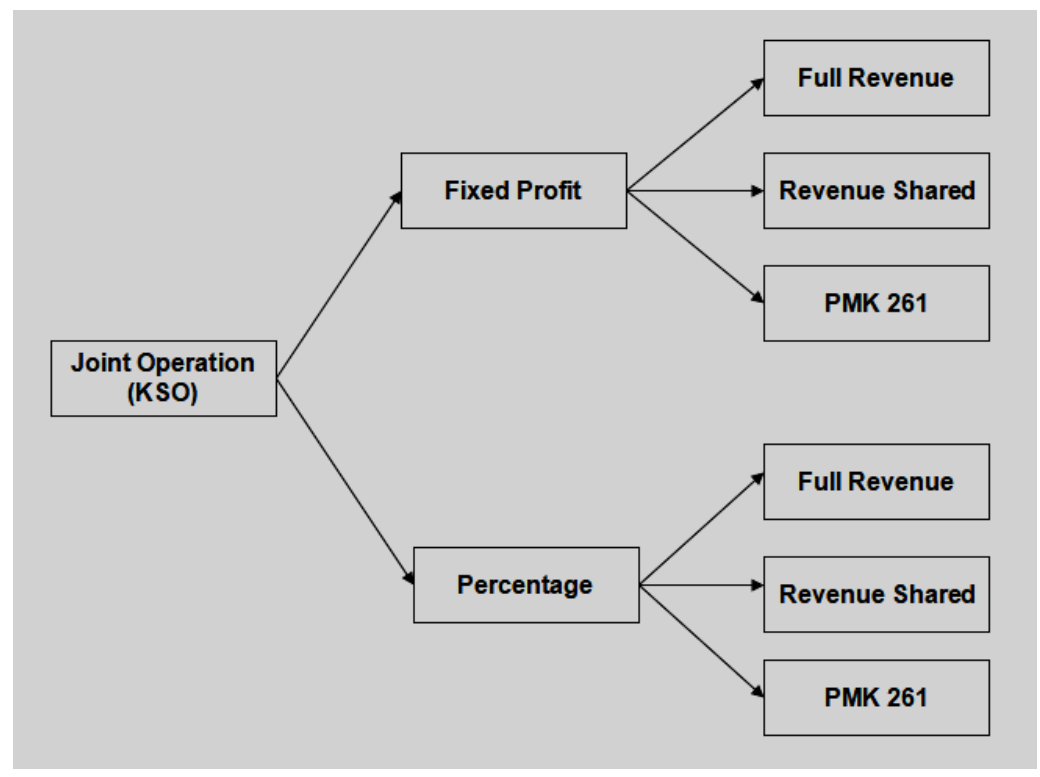

Figure 1. KSO Accounting method in general

Indar Khaerunnisa and Amrullah. Analysis on joint operation non administrative accounting models of property development firms and the impact on taxation 
Table 1. Comparison between three models

\begin{tabular}{|c|c|c|c|}
\hline Model & Full revenue & Profit-Sharing & PMK261 \\
\hline Fixed Profit & $\begin{array}{l}\text { - Commitment of profit } \\
\text { distribution stated at the } \\
\text { beginning } \\
\text { - } \text { Record sales and } \\
\text { COGS, } \\
\text { - Paying full tax (income } \\
\text { tax land and buildings) }\end{array}$ & $\begin{array}{l}\text { - } \text { Commitment of profit } \\
\text { distribution stated at the } \\
\text { beginning } \\
\text { - } \text { Record sales for value } \\
\text { building only } \\
\text { - Paying taxes on } \\
\text { building }\end{array}$ & $\begin{array}{l}\text { - Commitment of profit } \\
\text { distribution stated at the } \\
\text { beginning, Record sales and } \\
\text { COGS, } \\
\text { - Addition of DLBRA fees } \\
\text { - Paying full tax (income tax } \\
\text { land and buildings) }\end{array}$ \\
\hline Percentage & $\begin{array}{l}\text { - Profit distribution based on } \\
\text { the portion after } \\
\text { calculation of profit and } \\
\text { loss } \\
\text { - Record sales and COGS } \\
\text { - Pay full tax (income tax } \\
\text { land and buildings) }\end{array}$ & $\begin{array}{l}\text { - Profit distribution based } \\
\text { on the portion after } \\
\text { calculation of profit and } \\
\text { loss } \\
\text { - } \text { Record sales for value } \\
\text { building only } \\
\text { - Paying taxes on building }\end{array}$ & $\begin{array}{l}\text { - Profit distribution based on the } \\
\text { portion after calculation of } \\
\text { profit and loss } \\
\text { - Record sales and COGS, } \\
\text { additions of DLBRA fees } \\
\text { - Pay full tax (income tax } \\
\text { - land and buildings) }\end{array}$ \\
\hline
\end{tabular}

Note:

DLBRA: Duty on Land and Building Right Acquisition

\section{Fixed profit accounting model}

In the fixed profit accounting model, the profit sharing is calculated by dividing the profit at the beginning of the agreement according to the agreed portion. Distribution of profits which partners earn is according to the calculation at the beginning of the agreement so as whether the business sales gain profit or lost, it only affects the developer alone, but it does not affect the partner. This accounting model is highly recommended when sales in developers' side are experiencing an increase or exceed their sales targets. This fix profit accounting model is divided into 3 forms of recording of sales, consisting of:

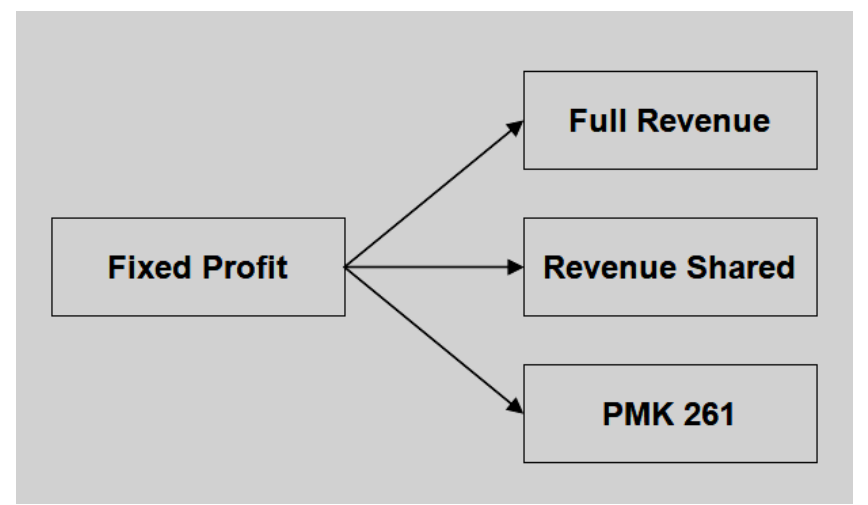

Figure 2. Fixed profit accounting model

\section{Fixed profit full revenue accounting model}

In accounting model of the joint operations with full revenue sales, the developer records sales of $100 \%$. The joint operations (KSO) fixed profit of full revenue accounting model can be seen from the simulation of the financial statements as follows: 
The Accounting Journal of BINANIAGA Vol. 05, No. 01, June 2020

p-ISSN: 2527-4309, e-ISSN: 2580-1481

$5^{\text {th }}$ Accreditation Rating: January 14, 2019 - January 13, 2024

Table 2. Full revenue accounting model fixed profit

\begin{tabular}{|l|c|c|l|c|c|}
\hline \multicolumn{2}{|c|}{ Grand Plan of Joint Operation } & \multicolumn{3}{c|}{ Fixed Full Revenue Model } \\
\hline Income plan & & 535.000 & & Developer & Partner \\
\hline Fixed Cost & & & Sales portion & $100 \%$ & $0 \%$ \\
\hline Land cost & 90.950 & & Sales & 535.000 & 0 \\
\hline Building cost & 214.000 & & Land cost & 90.950 & 0 \\
\hline Permit cost & 53.500 & & Building cost & 214.000 & 0 \\
\hline Marketing cost & 32.100 & & Permit cost & 53.500 & 0 \\
\hline Variable Cost & 21.400 & & Marketing cost & 32.100 & 0 \\
\hline Total cost & & 411.950 & Variable Cost & 21.400 & 0 \\
\hline Final income tax & & 13.375 & DLBRA fee & 0 & 0 \\
\hline $\begin{array}{l}\text { Profit after income } \\
\text { tax }\end{array}$ & & 109.675 & Total & 411.950 & 0 \\
\hline & & & Final income tax & 13.375 & 0 \\
\hline & & & Profit (loss) & 109.675 & 0 \\
\hline & & $\begin{array}{l}\text { Profit (loss) } \\
\text { share }\end{array}$ & 76.773 & 32.903 \\
\hline $\begin{array}{l}\text { Profit (Developer) } \\
70 \%\end{array}$ & $0 \%$ & 76.773 & Percentage (\%) & $70 \%$ & $30 \%$ \\
\hline Profit (partner) 30\% & & 32.903 & $\begin{array}{l}\text { When sale and } \\
\text { purchase } \\
\text { agreement } \\
\text { (accounting final } \\
\text { income tax) }\end{array}$ & 4.548 & 4.548 \\
\hline
\end{tabular}

In the fixed profit full revenue accounting model, there is a potential taxation problem. When sales and purchase agreement processes with consumers, the developer side must have 2 SSP consisting of income tax on land and buildings. For these problems, the developer must overbook the final income tax on land (property) conveyance income which has been paid and given by the developer in advance which will result in a reduction of the final income tax of Rp. 4.548 (30\% x Rp. 13.375). Thus, there is inequal result between sales and final income tax.

\section{Revenue-sharing fixed profit accounting model}

In this form of accounting tax for joint operation (KSO) fixed profit with sales, the developer does not recognize all sales because the partners also prefer to recognize the land as sales. The following is the accounting simulation of the fixed profit joint operation revenue-sharing.

Table 3. Model fix profit for revenue-sharing

\begin{tabular}{|l|c|c|l|c|c|}
\hline \multicolumn{2}{|c|}{ Master Plan of Joint Operation } & \multicolumn{3}{c|}{ Revenue-Sharing-Fixed Profit } \\
\cline { 4 - 6 } & & 535.000 & Sales portion & Developer & Partner \\
\hline Sale plan & & & Sales & $441.56 \%$ & $17,44 \%$ \\
\hline Fixed Cost & & & Land cost & - & 93.304 \\
\hline Land cost & 90.950 & & Building cost & 214.000 & 90.950 \\
\hline Building cost & 214.000 & & Permit cost & 53.500 & 0 \\
\hline Permit cost & 53.500 & & Marketing cost & 32.100 & 0 \\
\hline Marketing cost & 32.100 & & Variable Cos t & 21.400 & 0 \\
\hline Variable Cost & 21.400 & & DLBRA fee & 0 & 0 \\
\hline Total cost & & 411.950 & Dotal & 321.000 & 0 \\
\hline income tax Final & & 13.375 & Total & 11.042 & 2.333 \\
\hline Profit after income & & 109.675 & Final income tax & & \\
\hline
\end{tabular}

Indar Khaerunnisa and Amrullah. Analysis on joint operation non administrative accounting models of property development firms and the impact on taxation

Page : 48 


\begin{tabular}{|l|l|l|c|c|}
\hline \multicolumn{2}{|c|}{ Master Plan of Joint Operation } & \multicolumn{3}{c|}{ Revenue-Sharing-Fixed Profit } \\
\cline { 4 - 6 } & & & Developer & Partner \\
\hline tax & & & & \\
\hline & & Profit (loss) & 109.654 & 0 \\
\hline Profit (Developer) $70 \%$ & 76.773 & Profit (loss) share & 76.758 & 32.896 \\
\hline Profit (partner) 30\% & 32.903 & Percentage (\%) & $70 \%$ & $30 \%$ \\
\hline
\end{tabular}

Each of the developer and partner records income tax on land for partners in the amount of Rp. 2.333 and income of the building for developer accounting for Rp. 11.042. Each party records income tax on land and buildings so that the joint operation accounting model (KSO) for this revenue-sharing has no potential tax costs which will arise during the sale and purchase agreement process.

\section{PMK 261 fixed profit accounting model}

In fixed profit accounting model based on the provisions of PMK261, the developer records sales $100 \%$ while the partner recognizes sales in the form of the value of his/her land. The following is a simulation of accounting model based on PMK261 fixed profit joint operation tax:

Table 4. Accounting model based on PMK261

\begin{tabular}{|l|c|l|l|c|c|}
\hline \multicolumn{3}{|c|}{ Master Plan of Joint Operation } & \multicolumn{3}{c|}{ PMK261 Percentage Model } \\
\hline Income plan & & 535.000 .000 & & \multicolumn{1}{c|}{ Developer } & Partner \\
\hline Fixed Cost & & & Sale portion & $100,00 \%$ & $17,44 \%$ \\
\hline Land cost & 90.950 .000 & & Sale & 535.000 .000 & 93.304 .000 \\
\hline Building cost & 214.000 .000 & & Land cost & 90.950 .000 & 90.950 .000 \\
\hline Permit cost & 53.500 .000 & & Building cost & 214.000 .000 & 0 \\
\hline Marketing cost & 32.100 .000 & & Permit cost & 53.500 .000 & 0 \\
\hline Variable Cost & 21.400 .000 & & Marketing cost & 32.100 .000 & 0 \\
\hline Total cost & & 411.950 .000 & Variable Cost & 21.400 .000 & 0 \\
\hline income tax Final & 13.375 .000 & DLBRA fee & 4.547 .500 & 0 \\
\hline $\begin{array}{l}\text { Profit after income } \\
\text { tax }\end{array}$ & 109.675 .000 & Total & 416.497 .500 & 90.950 .000 \\
\hline \multicolumn{2}{|l|}{} & & & & \\
\hline Profit (Developer) $70 \%$ & & Final income tax & 13.375 .000 & 2.332 .600 \\
\hline Profit (partner) 30\% & & 76.772 .500 & Profit/loss sharing & 72.222 .593 & 32.904 .908 \\
\hline
\end{tabular}

The income tax of land conveyance and buildings has been recorded separately. In this partnership model, there is a decrease in profits due to the additional cost of Duty on Land and Building Right Acquisition. However, despite a decline in return on payment of Duty on Land and Building Right Acquisition fees, in the future there will be no tax risk which will arise because during the sale and purchase agreement process, the land is already in the developer's name.

\section{Percentage accounting model}

The percentage accounting model is the final profit sharing-based model. That is, profit sharing is divided when the joint operations (KSO) has calculated sales minus costs including tax obligations, then the net profit which has been calculated is directly multiplied by the percentage of profit/loss sharing ratio stated in the initial agreement (collaboration agreement). If the developer experiences a sale that does not reach the target, the partner bears the risk of loss because the profit-sharing position in this percentage model is determined when the profit (loss) calculation of the joint operations has been completed. In this accounting model, it is appropriate to use when the developer is predicted to experience a loss because the risk of the loss is not fully borne 
by the developer. The accounting taxation percentage model is divided into 3 forms, namely:

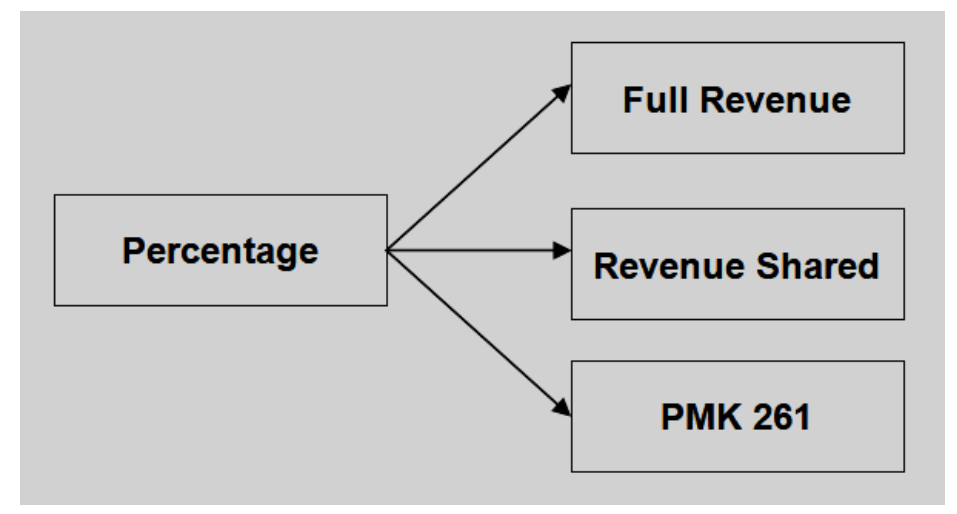

Figure 3. Percentage-based accounting model

\section{Model of accounting percentage of full revenue}

The accounting model of profit sharing by percentage and recognition of sales in full revenue is that in which the profit distributed to the developer and partner is calculated and allocated after the calculation of the profit/loss of the joint operation at a percentage determined at the beginning of the agreement. The developer records full sales of $100 \%$. For more details, the authors provide a simulation of the financial statements of the accounting for the joint operation. The scheme is depicted as follows:

Table 5. Accounting model of revenue percentage

Master Plant of Operation (KSO) Percentage Model Full Omzet

\begin{tabular}{|c|c|c|c|c|c|}
\hline $\begin{array}{l}\text { Income Plan } \\
\text { Fixed Cost }\end{array}$ & & 535.000 .000 & Sale Portion & $\begin{array}{c}\text { Developer } \\
100 \%\end{array}$ & $\begin{array}{c}\text { Partner } \\
0 \%\end{array}$ \\
\hline Land cost & 90.950 .000 & & Penjualan & 535.000 .000 & - \\
\hline Building cost & 214.000 .000 & & Land cost & 90.950 .000 & - \\
\hline Permit cost & 53.500 .000 & & Building cost & 214.000 .000 & 0 \\
\hline Marketing cost & 32.100 .000 & & Permit cost & 53.500 .000 & 0 \\
\hline Variable Cost & 21.400 .000 & & Marketing cost & 32.100 .000 & 0 \\
\hline Total cost & & 411.950 .000 & Variable Cost & 21.400 .000 & 0 \\
\hline income tax Final & & 13.375 .000 & DLBRA fee & - & 0 \\
\hline $\begin{array}{l}\text { Profit after income } \\
\text { tax }\end{array}$ & & 109.675 .000 & Total & 411.950 .000 & - \\
\hline & & & Final income tax & 13.375 .000 & - \\
\hline & & & Profit (loss) & 109.675 .000 & 0 \\
\hline & & & Profit/loss sharing & 76.772 .500 & 32.902 .500 \\
\hline \multicolumn{2}{|c|}{ Profit (Developer) $70 \%$} & 76.772 .500 & Percentage (\%) & $70,00 \%$ & $30,00 \%$ \\
\hline \multicolumn{2}{|l|}{ Profit (partner) 30\% } & 32.902 .500 & $\begin{array}{l}\text { When sale and } \\
\text { purchase } \\
\text { agreement } \\
\text { (accounting of } \\
\text { income tax Final) }\end{array}$ & 4.547 .500 & 4.547 .500 \\
\hline
\end{tabular}

When sale and purchase agreement process will be performed, the developer transfers the final income tax on land/property conveyance income which has been paid in advance by the developer in accordance with the portion of profit received by the partner as the landowner. So, at the time of the transfer of final income tax, the conveyance of land and sales with taxation recorded by the developers are not equal.

Indar Khaerunnisa and Amrullah. Analysis on joint operation non administrative accounting models of property development firms and the impact on taxation 
This will become a question from the tax service office (tax office) during the inspection. Another potential risk which will arise in this model is when profit-sharing in the form of joint operation of non-administrative KSO and does not have a tax ID on behalf of person involved in the joint operation, the tax office will assume that the profit sharing is partner's another income. Therefore, they must pay a corporate tax of $25 \%$ on the presumed other income.

\section{Accounting model of revenue-sharing percentage}

Accounting model of revenue-sharing percentage is a model in which the profit sharing is ended after the calculation of profit/loss of joint operations (KSO). Furthermore, the net profit of the KSO is immediately divided according to the percentage of profit/loss distribution stated in the initial agreement (cooperation agreement). Each party records separately and the sales value is different because not all sales are recognized by the developer. The following is a simulation of the financial statements of accounting based on revenue-sharing percentage:

Table 6. Accounting model of revenue-sharing percentage

\begin{tabular}{|l|c|c|l|c|c|}
\hline \multicolumn{2}{|l|}{ Master Plan of Joint Operation } & \multicolumn{3}{l|}{ Revenue Sharing Percentage Model } \\
\hline & & & & Developer & Partner \\
\hline Sale plan & & 535.000 & Sales portion & $82,56 \%$ & $17,44 \%$ \\
\hline Fixed Cost & & & Sales & 441.696 & 93.304 \\
\hline Land cost & 90.950 & & Land cost & - & 90.950 \\
\hline Building cost & 214.000 & & Building cost & 214.000 & 0 \\
\hline Permit cost & 53.500 & & Permit cost & 53.500 & 0 \\
\hline Marketing cost & 32.100 & & Marketing cost & 32.100 & 0 \\
\hline Variable Cost & 21.400 & & Variable Cost & 21.400 & 0 \\
\hline Total cost & & 411.950 & DLBRA fee & 0 & 0 \\
\hline income tax Final & & 13.375 & Total & 321.000 & 0 \\
\hline Profit after income tax & & 109.675 & Final income tax & 11.042 & 2.333 \\
\hline & & & Profit (loss) & 109.654 & 0 \\
\hline $\begin{array}{l}\text { Profit (Developer) } \\
70 \%\end{array}$ & & 76.773 & Profitloss sharing & 76.758 & 32.896 \\
\hline Profit (partner) 30\% & & 32.903 & Percentage (\%) & $70 \%$ & $30 \%$ \\
\hline
\end{tabular}

Each party records income tax on land for partners and income tax on buildings for developers. In the cooperation model of revenue-sharing, there is no potential tax costs which will arise when sale and purchase agreement process (sale and purchase agreement) is performed because each party has recorded taxation separately. Yet, when the profit-sharing between the developer and the partner is ended, the percentage model of revenue-sharing will result in the risk of corporate income tax since the tax office will assume that the profit-sharing is the partner's other income. Therefore, the partner must pay a tax of $25 \%$ on the other income.

\section{Accounting model based on PMK 261 percentage}

Accounting model of profit-sharing percentage with revenue recognition in accordance with PMK 261 is a model in which profit/loss for joint operation is calculated in advance. Then, it is directly charged according to the percentage of profit/loss distribution stated in the initial agreement/cooperation agreement (PKS). In this case, the developer records sales $100 \%$ and the partner recognizes the sale in the form of the value of his/her land. The following is a simulation of the financial statements of based on this model. 
The Accounting Journal of BINANIAGA Vol. 05, No. 01, June 2020

p-ISSN: 2527-4309, e-ISSN: 2580-1481

$5^{\text {th }}$ Accreditation Rating: January 14, 2019 - January 13, 2024

Table 7. Accounting model of profit-sharing percentage based PMK261

\begin{tabular}{|c|c|c|c|c|c|}
\hline \multicolumn{3}{|c|}{ Master Plan of Joint Operation } & \multicolumn{3}{|c|}{ PMK261 Percentage Model } \\
\hline Income plan & & 535.000 .000 & & Developer & Partner \\
\hline Fixed Cost & & & Sales portion & $100,00 \%$ & $17,44 \%$ \\
\hline Land cost & 90.950 .000 & & Sales & 535.000 .000 & 93.304 .000 \\
\hline Building cost & 214.000 .000 & & Land cost & 90.950 .000 & 90.950 .000 \\
\hline Permit cost & 53.500 .000 & & Building cost & 214.000 .000 & 0 \\
\hline Marketing cost & 32.100 .000 & & Permit cost & 53.500 .000 & 0 \\
\hline Variable Cost & 21.400 .000 & & Marketing cost & 32.100 .000 & 0 \\
\hline Total cost & & 411.950 .000 & Variable Cost & 21.400 .000 & 0 \\
\hline $\begin{array}{l}\text { income tax } \\
\text { Final }\end{array}$ & & 13.375 .000 & DLBRA fee & 4.547 .500 & 0 \\
\hline $\begin{array}{l}\text { Profit after } \\
\text { income tax }\end{array}$ & & 109.675 .000 & Total & 416.497 .500 & 90.950 .000 \\
\hline & & & Final income tax & 13.375 .000 & 2.332 .600 \\
\hline & & & Profit (loss) & 105.127 .500 & 0 \\
\hline Profit (Develope & $70 \%$ & 76.772 .500 & $\begin{array}{l}\text { Profit (loss) } \\
\text { sharing }\end{array}$ & 73.589 .250 & 31.538 .250 \\
\hline Profit (partner) & & 32.902 .500 & Percentage (\%) & $70 \%$ & $30,00 \%$ \\
\hline
\end{tabular}

The partner sells the land in cash in stages to the developer and the partner pay the land tax, then when the developer processes a sale and purchase agreement with a consumer, there is no potential loss because the land is already on behalf of the developer's name. The potential losses which will arise on the partners side is when the developer applies profit-sharing, the tax authority assumes it as the partner's other income other than land sales. Therefore, it is a subject to corporate income tax of $25 \%$.

\section{Analysis on the fixed profit accounting model}

From the three simulations outlined above using the fixed profit recording form, it is seen that the three forms have several accounting differences. Here are the differences in accounting for the three fixed profit models:

Table 8. Analysis of the fixed profit accounting model (in million Rp.)

\begin{tabular}{|c|c|c|c|c|c|c|}
\hline Remark & Sales & COGS & Tax & $\begin{array}{c}\text { Profit } \\
\text { Portion }\end{array}$ & $\begin{array}{c}\text { Sale and } \\
\text { Purchase } \\
\text { Agreement }\end{array}$ & $\begin{array}{c}\text { Developer's } \\
\text { Net Profit }\end{array}$ \\
\hline F1 & 535.000 & 411.950 & 13.375 & 76.773 & -4.013 & 80.785 \\
\hline F2 & 441.718 & 321.000 & 11.043 & 76.773 & - & 76.773 \\
\hline F3 & 535.000 & 416.498 & 13.375 & 72.225 & - & 72.225 \\
\hline
\end{tabular}

Remarks:

F1 = fixed profit full revenue accounting model,

F2 = fixed profit accounting model of revenue-sharing,

F3 = fixed profit accounting model of PMK 261

In the table above, we can clearly see the differences of each accounting model. The full revenue fixed profit accounting model records sales of Rp.535.000 less than COGS which consists of land and non-land costs, i.e. Rp. 411.950. It is because this model recognizes full sale, the tax paid according to the sale multiplied by $2.5 \%$ of the income tax as conveyance of land and buildings of Rp. 13.375. Thus, the net profit earned by the developer is Rp. 76.773 (70\% of the profit/loss of the joint operation). In addition, in this model, when sale and purchase agreement process will be carried out with consumers, the developer must carry out the payment of income tax as conveyance 
of land and buildings which have been paid for Rp. 4.013 (30\% of the final income) so that the final income tax is reduced to Rp. 9.363. In the end, the developer gains a net profit of Rp. 80.785. However, when the developer is performing a tax audit, tax office questions will be related to final income tax and inequal sales.

In the fixed profit revenue-sharing accounting model above, the developer only records sales other than the land value of $\mathrm{Rp} .441 .718$ reduced costs including building costs, licensing fees, marketing costs and overhead costs of Rp. 321.000. Then, they pay taxes on building conveyance of Rp. $11.043(2.5 \% \times$ sales price) that is net profit obtained by the developer, Rp. 76.773. In this accounting model, the tax obligations are borne individually so that there is no overbook activity on land \& building income tax.

In the fixed profit based on PMK 261 accounting model described above, the developer records full sales of Rp. 535.000 less all Duty on Land and Building Right Acquisition fees and costs of Rp. 416.498 and then pay taxes on all recognized sales which is $2.5 \%$ of the sales of Rp. 13.375. So, the developer earns a profit from the joint operation profit sharing of Rp. 72.225. When the sale purchase agreement process with consumers does not need to do overbook because the developer has made a return on the name of the land.

Of the three fixed profit models, the differences of which have been compared, in perspective of profit, it is better to use the full revenue fixed profit model. However, the model is risky because sales with paid income tax is not equal and the regulations governing the model are no longer valid. When viewed from the taxation regulations, the PMK261 fixed profit model is preferable because the model is safe in its taxation obligations and there are government regulations governing this model.

\section{Analysis of percentage accounting model}

In the accounting model of percentage discussed in above, there are also three different forms of in their accounting. The difference is seen in the table below.

Table 9. Analysis on percentage accounting model (in million Rp.)

\begin{tabular}{|c|c|c|c|c|c|c|}
\hline Remark & Sales & COGS & Tax & $\begin{array}{c}\text { Profit } \\
\text { Portion }\end{array}$ & $\begin{array}{c}\text { Sale and } \\
\text { Purchase } \\
\text { Agreement }\end{array}$ & $\begin{array}{c}\text { Developer's Net } \\
\text { Profit }\end{array}$ \\
\hline P1 & 535.000 & 411.950 & 13.375 & 76.773 & -4.013 & 80.785 \\
\hline P2 & 441.718 & 321.000 & 11.043 & 76.773 & - & 76.773 \\
\hline P3 & 535.000 & 416.498 & 13.375 & 73.589 & - & 73.589 \\
\hline
\end{tabular}

Remarks:

$\mathrm{P} 1=$ Percentage accounting model of full revenue,

$\mathrm{P} 2$ = accounting model on percentage of revenue-sharing,

P3 = percentage accounting model of PMK261

Similar to fixed profit model above, of the three percentage models the difference of which have been compared, when viewed in profitably perspective, it is better to use the full revenue percentage model. However, the model is at risk of taxation because sales with income tax paid are not equal and the regulations which allow overbook are it is no longer valid. If it complies with its taxation regulations, the PMK 261 percentage model is better because the model is safe in its taxation obligations and there are government regulations governing the PMK 261 percentage model. 
The Accounting Journal of BINANIAGA Vol. 05, No. 01, June 2020

p-ISSN: 2527-4309, e-ISSN: 2580-1481

$5^{\text {th }}$ Accreditation Rating: January 14, 2019 - January 13, 2024

\section{Comparison of fixed profit and percentage in PMK261 model}

Table 10. Tax accounting models of revenue-sharing percentage

\begin{tabular}{|l|c|c|l|c|c|}
\hline \multicolumn{2}{|l|}{ Master Plan of Joint Operation } & \multicolumn{3}{l|}{ Profit-Sharing Percentage Model } \\
\hline Income plan & & 535.000 .000 & & \multicolumn{1}{l|}{ Developer } & Partner \\
\hline Fixed Cost & & & Sales portion & $82,56 \%$ & $17,44 \%$ \\
\hline Land cost & 90.950 .000 & & Sales & 441.696 .000 & 93.304 .000 \\
\hline Building cost & 214.000 .000 & & Land cost & & 90.950 .000 \\
\hline Permit cost & 53.500 .000 & & Building cost & 214.000 .000 & 0 \\
\hline Marketing cost & 32.100 .000 & & Permit cost & 53.500 .000 & 0 \\
\hline Variable Cost & 21.400 .000 & & Marketing cost & 32.100 .000 & 0 \\
\hline Total cost & & 411.950 .000 & Variable Cost & 21.400 .000 & 0 \\
\hline income tax Final & 13.375 .000 & DLBRA fee & - & 0 \\
\hline $\begin{array}{l}\text { Profit after income } \\
\text { tax }\end{array}$ & 109.675 .000 & Total & 321.000 .000 & 90.950 .000 \\
\hline \multicolumn{2}{|l|}{} & & Final income tax & 11.042 .400 & 2.332 .600 \\
\hline & & Profit (loss) & 109.653 .600 & 0 \\
\hline \multicolumn{2}{|l|}{} & & Profit (loss) sharing & 76.757 .520 & 32.896 .080 \\
\hline Profit (Developer) 70\% & 76.772 .500 & Percentage (\%) & $70.00 \%$ & $30,00 \%$ \\
\hline Profit (partner) 70\% & 32.902 .500 & $\begin{array}{l}\text { when sale and } \\
\text { purchase agreement } \\
\text { (accounting of } \\
\text { income tax Final) }\end{array}$ & - & - \\
& & & & \\
\hline
\end{tabular}

Each party records income tax on land for partners and income on buildings for developers. In cooperation model for this revenue, there is no potential tax costs that will arise during the sale purchase agreement because each party has recorded taxation separately. But when the profit sharing between the developer and the partner is ended, the percentage model for this revenue will result in the risk of corporate income tax because the tax office will assume that the profit sharing is other income of the partner. Then the partner must pay a tax of $25 \%$ on the other income.

\section{Accounting model of PMK 261 percentage}

Accounting model of profit-sharing percentage with revenue recognition in accordance with PMK 261 is that profit/loss for operational cooperation which is calculated in advance, then directly charged according to the percentage of profit/loss distribution stated in the initial agreement /cooperation agreement (PKS). In this case, the developer records a $100 \%$ sale and the partner recognizes the sale in the form of the value of his/her land. The following is a simulation of the financial statements of percentage of PMK261.

Table 11. Accounting model of PMK261 percentage

\begin{tabular}{|l|c|c|l|c|c|}
\hline \multicolumn{2}{|c|}{ Master Plan of Joint Operation } & \multicolumn{3}{c|}{ PMK261 Percentage Model } \\
\hline Income plan & & 535.000 .000 & & Developer & Partner \\
\hline Fixed Cost & & & Sales portion & $100,00 \%$ & $17,44 \%$ \\
\hline Land cost & 90.950 .000 & & Sales & 535.000 .000 & 93.304 .000 \\
\hline Building cost & 214.000 .000 & & Land cost & 90.950 .000 & 90.950 .000 \\
\hline Permit cost & 53.500 .000 & & Building cost & 214.000 .000 & 0 \\
\hline Marketing cost & 32.100 .000 & & Permit cost & 53.500 .000 & 0 \\
\hline Variable Cost & 21.400 .000 & & Marketing cost & 32.100 .000 & 0 \\
\hline Total cost & & 411.950 .000 & Variable Cost & 21.400 .000 & 0 \\
\hline income tax & & 13.375 .000 & DLBRA fee & 4.547 .500 & 0 \\
\hline
\end{tabular}

Indar Khaerunnisa and Amrullah. Analysis on joint operation non administrative accounting models of property development firms and the impact on taxation

Page : 54 


\begin{tabular}{|l|l|l|l|l|c|}
\hline \multicolumn{2}{|c|}{ Master Plan of Joint Operation } & \multicolumn{3}{c|}{ PMK261 Percentage Model } \\
\hline Final & 109.675 .000 & Total & 416.497 .500 & 90.950 .000 \\
\hline $\begin{array}{l}\text { Profit after } \\
\text { income tax }\end{array}$ & & & Final income tax & 13.375 .000 & 2.332 .600 \\
\hline & & & Profit (loss) & 105.127 .500 & 0 \\
\hline & & & Profit-loss Sharing & 73.589 .250 & 31.538 .250 \\
\hline Profit (Developer) $70 \%$ & 32.902 .500 & Percentage (\%) & $70,00 \%$ & $30,00 \%$ \\
\hline \multicolumn{2}{|l|}{ Profit (partner) $70 \%$} & & & & \\
\hline
\end{tabular}

The partner sells the land in cash in stages to the developer and the partner pays land tax. Then, when the developer processes the sale and purchase agreement with the consumer, there is no potential loss because the land is already in the developer's name. Potential losses which will arise on the partners side is when the developer does profit-sharing, the tax authority considers it as the partner's other income other than land sales. Thus, it is subjected to corporate income tax of $25 \%$.

\section{Analysis of the fixed profit accounting model}

Of the three simulations using the fixed profit accounting model outlined above, it can be seen that in all three forms, there are some different accounting. Here are the differences in accounting for the three fixed profit models:

Table 12. Analysis of fixed profit accounting model (in million Rp.)

\begin{tabular}{|c|c|c|c|c|c|c|}
\hline Remark & Sales & COGS & Tax & $\begin{array}{c}\text { Profit } \\
\text { Portion }\end{array}$ & $\begin{array}{c}\text { Sale and } \\
\text { Purchase } \\
\text { Agreement }\end{array}$ & $\begin{array}{c}\text { Developer's } \\
\text { Net Profit }\end{array}$ \\
\hline F1 & 535.000 & 411.950 & 13.375 & 76.773 & -4.013 & 80.785 \\
\hline F2 & 441.718 & 321.000 & 11.043 & 76.773 & - & 76.773 \\
\hline F3 & 535.000 & 416.498 & 13.375 & 72.225 & - & 72.225 \\
\hline
\end{tabular}

Remarks:

$\mathrm{F} 1=$ fixed profit full revenue accounting model,

F2 = fixed profit revenue-sharing accounting model,

F3 = accounting model of PMK261

In the table above, we can clearly see the differences in accounting in each form of fixed profit accounting. The full revenue fixed profit accounting model records sales of Rp. 535.000 less COGS which consists of land and non-land costs Rp. 411.950. Because this model recognizes the full sale, the tax paid according to the sale multiplied by $2.5 \%$ of the income tax transfer of land and buildings of Rp. 13.375. So, net profit obtained by the developer is Rp. 76.773 ( $70 \%$ of the profit / loss of the joint operation). In addition, in this model, when sale and purchase agreement process with consumers is carried out, the developer must perform income tax handover of land and buildings which have been paid for Rp. 4.013 (30\% of the final income tax). So, the final income tax is reduced to $\mathrm{Rp}$. 9.363. In the end, the developer earns a net profit of Rp. 80.785. However, when the developer is undergoing a tax audit, tax office questions is related to final income tax and inequal sales.

In the fixed profit revenue-sharing accounting model above, the developer only records sales other than the land value of $\mathrm{Rp}$. 441.718 subtracted with costs including building costs, licensing fees, marketing costs and overhead costs of Rp. 321.000, then taxes payment on building handover of Rp. 11.043 (2.5\% x sales price), so that the net 
profit earned by the developer is Rp. 76.773. In this accounting model, the tax obligations are borne individually so that there is no overbook activity on land \& building income tax.

In the fixed profit PMK 261 accounting model described above, the developer records full sales of Rp. 535,000 less all BPHTB fees and costs of Rp. 416.498 and then pay taxes on all recognized sales which is $2.5 \%$ of the sales of Rp. 13.375 . Thus, the developer earns a profit from the joint operation profit-sharing amounting to Rp. 72.225. During the sale and purchase agreement process with the consumer, there is no need to do overbook because the developer has made a return on the land.

Of the three fixed profit models the difference of which have been compared, when viewed in profit, it is better to use the full revenue fixed profit model. Yet, the model is risky because sales with income tax paid are not equal and the regulations governing the model are no longer valid. If viewed from the taxation regulations, the PMK261 fixed profit model is better because the model is safe in its taxation obligations and there are government regulations governing the model.

\section{Analysis of percentage accounting model}

In the percentage accounting model discussed earlier, the three forms of percentage accounting have differences in their accounting which can be observed from the table below.

Table 13. Analysis of percentage accounting model (in million Rp.)

\begin{tabular}{|c|c|c|c|c|c|c|}
\hline Remark & Sales & COGS & Tax & $\begin{array}{c}\text { Profit } \\
\text { Portion }\end{array}$ & $\begin{array}{c}\text { Sale and } \\
\text { Purchase } \\
\text { Agreement }\end{array}$ & $\begin{array}{c}\text { Developer's } \\
\text { Net Profit }\end{array}$ \\
\hline P1 & 535.000 & 411.950 & 13.375 & 76.773 & -4.013 & 80.785 \\
\hline P2 & 441.718 & 321.000 & 11.043 & 76.773 & - & 76.773 \\
\hline P3 & 535.000 & 416.498 & 13.375 & 73.589 & - & 73.589 \\
\hline
\end{tabular}

Remarks:

P1 = Accounting Model of Full Revenue Percentage

P2 = Accounting Model of Percentage for Revenue

P3 = Accounting Model of Percentage of PMK261

Just like the Fixed profit model above, of the three percentage models, the differences of which have been compared, if viewed the profitably, it is better to use the full revenue percentage model. But the model is at risk of taxation because sales with income tax paid are not equal and the regulations that allow overbook are it is no longer valid.

\section{Comparison of fixed profit model and percentage in PMK261}

Based on the differences explained above, fixed profit and percentage models experience the same difference so that the author will compare the form of PMK261 with the fixed profit and percentage models. In the following table, differences of the two models can be observed. 
Table 14. Comparison of fixed profit and percentage model

\begin{tabular}{|c|c|c|c|c|c|c|}
\hline Remark & Sales & COGS & Tax & Profit portion & $\begin{array}{c}\text { Sale and } \\
\text { Purchase } \\
\text { Agreement }\end{array}$ & $\begin{array}{c}\text { Developer's Net } \\
\text { Profit }\end{array}$ \\
\hline F3 & 535.000 & 416.498 & 13.375 & 72.225 & - & \\
\hline P3 & 535.000 & 416.498 & 13.375 & 73.589 & - & \\
\hline
\end{tabular}

Information:

F3 = PMK261 fixed profit accounting model

P3 = percentage of PMK261 accounting model

In the comparison table between the fixed profit and the percentage accounting model above, it can be observed that the sales value and cost of goods sold are considered the same in the record, which is Rp. 535.000 for sales and cost of goods sold recorded at Rp. 416.498. In terms of taxation, the value recorded by the two models is similar, amounting to Rp. 13.375 because both models recognize $100 \%$ sales and must pay taxes according to the sales portion. In each choice made, there is accompanying risk which must be faced and how to overcome.

\begin{tabular}{|c|c|c|c|c|}
\hline \multirow{2}{*}{$\begin{array}{c}\text { Goal / } \\
\text { Target / } \\
\text { Activities }\end{array}$} & \multicolumn{3}{|c|}{ Risks } & \multirow{2}{*}{$\begin{array}{c}\text { Existing Positive } \\
\text { Factor (to Mitigate } \\
\text { Risks) }\end{array}$} \\
\hline & Event & $\begin{array}{c}\text { Main Cause of } \\
\text { Risk }\end{array}$ & Consequence & \\
\hline $\begin{array}{l}\text { Knowing the } \\
\text { comparison of } \\
\text { the fixed profit } \\
\text { Model with the } \\
\text { percentage } \\
\text { model for } \\
\text { measuring joint } \\
\text { operation and } \\
\text { the impact it } \\
\text { causes }\end{array}$ & $\begin{array}{l}\text { Based on the sales } \\
\text { target achieved, the } \\
\text { percentage model } \\
\text { can produce a } \\
\text { higher or lower } \\
\text { value than the fixed } \\
\text { profit model }\end{array}$ & $\begin{array}{l}\text { The calculation of } \\
\text { the percentage } \\
\text { model uses joint } \\
\text { operation net profit } \\
\text { in calculating the } \\
\text { portion of partner's } \\
\text { profit when profit } \\
\text { sharing is } \\
\text { performed }\end{array}$ & $\begin{array}{l}\text { The increase/ } \\
\text { decrease in value } \\
\text { affects profit or loss } \\
\text { of a company }\end{array}$ & $\begin{array}{l}\text { Developers analyze } \\
\text { when using the } \\
\text { percentage model in } \\
\text { calculating profit sharing }\end{array}$ \\
\hline
\end{tabular}

\section{CONCLUSIONS}

Based on the analysis and discussion which have been done, the authors can draw some conclusions. Based on the results obtained from the comparative analysis of the fixed profit accounting model, from the three forms of fixed profit including fixed profit full revenue, fixed profit revenue-sharing and fixed profit of PMK 261, it shows that when viewing profitably, it is better to use the fix profit full revenue model. However, the model is risky because sales with taxes paid are not equal and the regulations governing the model are no longer valid. When viewed from the taxation regulations, the PMK 261 fixed profit model is preferable because the model is safe in its taxation obligations and there are government regulation provisions governing the model. Furthermore, the results obtained from the comparison of the percentage accounting model analysis are the same as the fixed profit model. Of the three percentage models the difference of which have been compared, when viewed profitability, it is better to use the full revenue percentage model. Yet, the model is at risk because sales with the tax paid are not equal and the rules governing the model are no longer valid. If it complies with its tax regulations, the PMK 261 percentage model is recommended because the model is safe in its taxation obligations and there are government regulations that govern the PMK261 percentage model. Meanwhile the results of the comparison between PMK261 fixed profit accounting and PMK261 accounting percentage is seen from the same accounting sales value and cost of goods sold. When viewed from the profit portion, the two accounting models (fixed

Indar Khaerunnisa and Amrullah. Analysis on joint operation non administrative accounting models of property development firms and the impact on taxation 
profit and percentage model), there are differences which are caused by the sharing of profits. In the fixed profit model, the nominal profit distribution that the partners will earn is determined and agreed at the beginning of the agreement. Meanwhile, in the percentage model, the distribution of partner's profit is made after calculating the joint operation profit / loss. Then, after the calculation, a net profit will be obtained which has been deducted from all tax obligations and the net profit is subject to a percentage which is according to the initial agreement of the operational cooperation.

In terms of land and building tax, the values recorded by the two models are the same because both models recognize $100 \%$ sales and must pay tax according to the sales amount. The taxation problems which will arise for the partner are the percentage accounting model, which will cause corporate tax for the partner. It is because the tax office will assume the profit sharing is the partner's other income, which will be charged at $25 \%$ of the partner's income.

\section{RECOMMENDATIONS}

Based on the conclusions above, the authors propose several recommendations which can be used for consideration:

The most recommended form of accounting is all forms of those in accordance with PMK 261, both the fixed profit and percentage models because of the minimal tax risk which will arise in the future. In addition, the model is in accordance with the regulations which currently apply. Based on the simulations results presented in the previous chapters, when the developer conducts an operational cooperation with the landowner, it is recommended to use the percentage accounting model. It is because that the business is risky so that the loss or profit is borne together when viewed from the profit between fixed profit and the percentage using the percentage model. But the percentage model will entail corporate tax on partners because the tax office assumes that the distribution of the final profit is the partner's other income which will be charged a rate of $25 \%$ of the income.

Before carrying out joint operations, it is advised to consider it more when determining the accounting model. If the developer is optimistic that it will reach or even exceed the target, it is better to use the fixed profit model because the developer' will earn the entire profit. But, if the pessimistic company does not reach the target and estimates that there will be more risks in the future, the accounting model is recommended to use a percentage model because when the targets are not achieved or even losses due to risks which occur, the loss is shared together with partners.

\section{REFERENCES}

Arikunto, Suharsimi. 2010. Prosedur Penelitian Suatu Pendekatan Praktek, Jakarta: Rineka Cipta. Peraturan Pemerintah Republik Indonesia Nomor 261/PMK.03/2016.

Resmi, Siti. 2013. Perpajakan Teori dan Kasus. Jakarta: Salemba Empat. Siti, Kurni Rahayu. 2010.

PERPAJAKAN INDONESIA: Konsep dan Aspek Formal. Yogyakarta: Graha Ilmu. Sugiono. 2009. Metode Penelitian Kuantitatif, Kualitatif dan R\&D. Bandung: Alfabeta. Sumarsan, Thomas. 2013. Perpajakan Indonesia: Edisi3. Jakarta: PT. Indeks.

Surat Dirjen Pajak Nomor S-323/PJ.42/1989 Tanggal 06 Desember 1989. UndangUndang Republik Indonesia Nomor 13 Tahun 1985.

Indar Khaerunnisa and Amrullah. Analysis on joint operation non administrative accounting models of property development firms and the impact on taxation 
The Accounting Journal of BINANIAGA Vol. 05, No. 01, June 2020

p-ISSN: 2527-4309, e-ISSN: 2580-1481

$5^{\text {th }}$ Accreditation Rating: January 14, 2019 - January 13, 2024

Undang-Undang Republik Indonesia Nomor 42 Tahun 2009.

Undang-Undang Nomor 28 Tahun 2007 Tentang Ketentuan Umum dan Tata Cara Perpajakan. Waluyo. 2011. Perpajakan Indonesia. Jakarta: Salemba Empat. 
The Accounting Journal of BINANIAGA Vol. 05, No. 01, June 2020

p-ISSN: 2527-4309, e-ISSN: 2580-1481

$5^{\text {th }}$ Accreditation Rating: January 14, 2019 - January 13, 2024

This page intentionally be emptied.

Indar Khaerunnisa and Amrullah. Analysis on joint operation non administrative accounting models of property development firms and the impact on taxation

Page : 60 